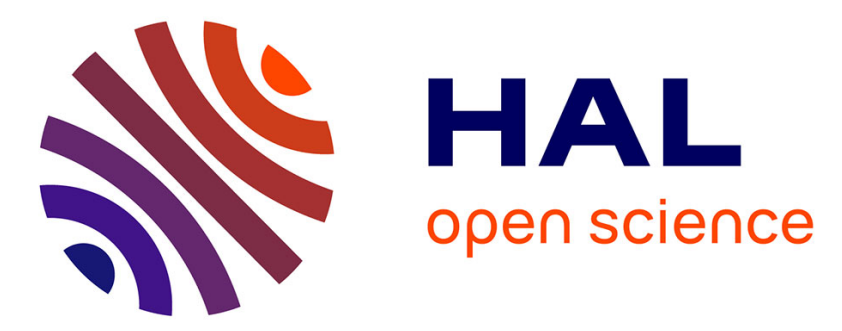

\title{
Integrating water resource management and land-use planning at the rural-urban interface: Insights from a political economy approach
}

\author{
Christophe Boschet, M. Rambonilaza
}

\section{- To cite this version:}

Christophe Boschet, M. Rambonilaza. Integrating water resource management and land-use planning at the rural-urban interface: Insights from a political economy approach. Water Resources and Economics, 2015, 9, pp.45-59. 10.1016/j.wre.2014.11.005 . hal-01140270

\author{
HAL Id: hal-01140270 \\ https://hal.science/hal-01140270
}

Submitted on 8 Apr 2015

HAL is a multi-disciplinary open access archive for the deposit and dissemination of scientific research documents, whether they are published or not. The documents may come from teaching and research institutions in France or abroad, or from public or private research centers.
L'archive ouverte pluridisciplinaire HAL, est destinée au dépôt et à la diffusion de documents scientifiques de niveau recherche, publiés ou non, émanant des établissements d'enseignement et de recherche français ou étrangers, des laboratoires publics ou privés. 


\title{
Integrating water resource management and land-use planning at the rural- urban interface: insights from a political economy approach ${ }^{1}$
}

\author{
Christophe Boschet and Tina Rambonilaza
}

\begin{abstract}
Institutional obstacles to integrated water management at the river basin scale have been discussed in detail in the water governance literature, but there has been less attention to the development of analytical framework for understanding local government cooperation. In this study, a median voter model was developed to describe the political processes by which municipalities lend their support to land-use control in river basin management planning. Relative income, population growth, and land cover data - as measured at municipality level - are advanced to be the main determinants of municipalities' positioning on additional environmental zoning. The consultation process for the SAGE (Planning and water management scheme) for the Gironde estuary and associated areas was used as a case study. Spatial logit estimation of the determinants of the results of voting in this consultation process suggests that municipalities' decisions are strongly influenced by the landscape preferences of the median voter. Acceptance of the SAGE project is an increasing function of relative income and population growth, as measured at municipality level. Furthermore, the municipalities that reject it are mainly those with the largest agricultural areas. The results confirm the existence of a very strong political component in the process by which a municipality decides whether or not to support a river basin plan. This decision can be linked to the preservation of natural landscape amenities in peripheral areas, while elsewhere it is connected to the protection of farming. Theoretical and empirical developments of political economy analysis provide an alternative framework by which to understand institutional fits and interplay in water resource management.
\end{abstract}

Keywords: Environmental zoning ; landscape preferences ; river basin management ; median voter; France

1 This study received funding from the French ministry of Ecology, Sustainable Development and Energy, in the "Eaux et Territoires" research program (16/10/2010), convention n²100 170383 . The usual disclaimer applies. 


\section{Introduction}

In the early 2000's, the implementation of the European Union Water Framework Directive (WFD) introduced the principles of river basin management planning (RBMP), to ensure that the objectives of good status of all water bodies across Europe could be achieved by 2015. However, an assessment of the first generation of RBMP [1] highlighted that there was still room for improvement in the field of water management. This same assessment recommended that further efforts were to be made to manage water resources in a more "integrated" fashion. Many scholars have argued that the integration of water resource management is first and foremost a problem of institutional fit and interplay [2], [3], [4], [5] and [6]. Furthermore, the notion of "integration" covers two very different definitions in terms of water governance [7]. It can refer to the joint management of water issues under the umbrella of a single body (the river basin authority) or the collaborative management of water by different parallel sectors with the help of more flexible institutional arrangements to allow greater involvement of stakeholders and social learning [8-9]. Thus, the implementation of more integrated management of water resources in the European context will require welldefined coordination structures to be effective, regardless of which RBM concept is under concern.

The WFD calls for the use of a RBM approach in cases where political or administrative boundaries may constitute obstacles to good water governance. From a normative standpoint, the RBM approach would appear to be the logical institutional answer to longstanding externality and coordination problems between local governments [10] in water resource management. It is designed to tackle the problem of spatial misfit between the territorial units of political decision-making and boundaries of biophysical processes [11]. This incompatibility exists notably in the coordination of upstream and downstream uses of rivers [12-13], the protection of surface and ground water quality [5] and the integration of water issues with land-use planning for flood control and wetland protection [14]. The implementation of river basin management planning has therefore taken precedence over existing political and administrative competencies [1] and [15]. However, questions remain as to the institutional barriers to effective river basin management plan. In practice, this has 
meant that successful implementation of RBMP has often been impeded by local opposition to the centralised principles of river basin planning [16].

With regard to the integration of land-use planning and water management, the advantage of planning on a river basin basis is that it may be most beneficial to the stream as a whole. Municipalities are thus given specific responsibilities within institutional arrangements for RBM, since they often hold the local monopoly on planning [17], [18] and [19]. In real terms, this monopoly means that they have the power to define, develop and implement policies regulating land use. However, their involvement in the planning process for water resource management has fallen short of expectations, since they still give priority to their own political interests, with decisions still heavily influenced by local economic and social issues [20] and [21]. As a result, land-use planning based around water resource management principles may not fully achieve its potential benefits, due to incompatibility between the goals of river basin management and the political interests of the local governments.

This study provides evidence consistent with this explanation. Indeed, there is some temptation to argue that because watersheds or river basins are generally not aligned with conventional electoral boundaries, the usual pathways of political accountability do not necessarily apply. However, in the current era of decentralisation and increasing demands from the general public for accountability in local policy decision-making, locally elected officials who are called upon to participate in river basin management initiatives remain responsible for, and accountable to, the jurisdictions in which they were elected [22]. This article builds on the literature on the political economy of land use regulation to make an analytical contribution to the evolving literature on institutional and policy analysis of RBMP implementation [23], [24] and [7]. While the question of how different water management options are identified and put forward has been the subject of a number of previous studies, the reasons why some of them are not selected by local stakeholders has yet to be examined in-depth.

The empirical study is based on the analysis of the positions of 151 French rural and peripheral municipalities targeted for the implementation of the SAGE (Planning and water management scheme) for the Gironde estuary and its associated areas. The new spatial planning strategy used for the management of the Gironde estuary is aimed at limiting residential development in the rural and peripheral areas of the urban region of Bordeaux, restoring wetland ecosystem functions and making additional space for the river within the flood plain. Following the administrative procedure for the implementation of RBMP in 
France, the plan was put to a vote of elected officials in December 2012. Not surprisingly, some of the municipalities concerned rejected it, leading to renewed negotiations. The upshot of these negotiations was that maps of future flood plains and wetland protection areas were removed in order to reach a consensus.

A simple median voter model [25] was used to frame the analysis of locally elected officials' decisions on the land planning aspects of water resource management. The model represents a departure from approaches based on land market values [26] and [27]. It provides a testable hypothesis relating to the residential demand for non-market values of landscape preservation and quality of life. Our hypothesis is that a local official (mayor) chasing reelection will seek to comply with the environmental demands of their voters. In the best case scenario, that official will support the river basin plan. In the worst case, they will actively oppose it. By using Conley's [28] spatial logit estimation method, it was possible to correct spatial autocorrelation of error terms, and accurately test the relative influence of the variables of interest on the positions adopted by various municipalities.

The remainder of the article is structured as follows: The second section gives details on the theoretical model. The third section briefly introduces the estimation method, before presenting the case study (the consultation phase of the SAGE project for the Gironde estuary and its associated areas in France) and the data used. The fourth section develops the econometric analysis of the determinants of elected officials' decisions and presents the results. The fifth section discusses these results, before concluding.

\section{A theoretical framework}

2.1. A political economy of land-use restriction in rural and peripheral areas

Land-use and land-cover change are one of the main factors in growing human pressure on natural resources observed in most European regions [29]. Zoning policies and strategic planning have therefore become the most relevant tools for regulating urban growth and protecting the natural environment [30]. For water management, land-use control through zoning is also required to contain urban growth boundaries, to protect critical terrestrial and aquatic habitats from land conversion, and to maintain open spaces. Implemented in this way, integration of land-use planning and water resource management by environmental zoning is aligned with nature development in rural areas. Such policies tend to pander to demands from new resident populations, who generally have an interest in preserving a specific landscape or 
natural amenity [31], [32], [33], [34] and [35]. In contrast, such policies can penalise native people (long-time residents and farmers) who still depend on agriculture and related activities for their livelihoods. Land-use controls can accentuate land pressure, resulting in higher farmland prices in remote rural areas. It also leads to acceleration in the rate at which farmland close to urban areas is converted for residential use [36] and [37]. This increased residential development is accompanied by a decrease of agriculture employment and an increase in long-term residents working in the service sector [38]. Hence, new residents and non-farmers tend to favour natural landscapes, whereas natives and farmers support the defense of agrarian environments. The different non-market economic values attached to landscape patterns by the members of these two groups [39-41] may be explained by this phenomenon.

The heterogeneous nature of the landscape preferences of municipality residents may also be the source of the intense lobbying and negotiation surrounding land-use planning at river basin level. Acceptance or rejection of environmental zoning varies from one municipality to another. This means that it is far from straightforward to identify the process guiding the local authorities' decisions about river basin land-use planning. However, the extensive existing literature on the political economy of land use regulation [42], [43], [44], [45] and [26] can give a framework for understanding the politics behind zoning decisions. They emphasise that (environmental) zoning reflects the interests of the social group controlling the political process. Usually, three major interest groups (homeowners, land developers, and owners of undeveloped land) who might benefit from certain types of landuse change are thought to invest in lobbying activities to influence the decision of the local policy-maker. However, in jurisdictions with higher electoral competition [45], the latter might find in turn that it would be difficult to refuse the policies desired by homeowners, who also represent the median voter [43].

The 'homevoter hypothesis' thus implies that locally elected officials establish their zoning decision in order to win the approval of the majority of the resident population likely to benefit from "specific" land-use restrictions. In addition to considering the median voter in the lobbying process for land-use regulation, recent studies have suggested taking into account the interests of "land groups" (landowners and land-developers), thus providing a broader framework for analysis. This study derives its testable hypothesis directly from the "median voter model", by departing from the more common approaches based on land market values. As mentioned above, changes in landscape patterns are highly valued, not only for their market perspective. They are an important contributor to the quality of life for people 
living in rural and peripheral areas. For this reason, landscape quality appears to be a local public good - one that can be enjoyed mainly by residents in the local community, and its preservation becomes one of the main issues in rural policy-making [46] and sustainable development strategies [47]. In addition, it has been shown that in France, people living in rural areas are more likely to participate in municipal elections than those living in urban areas [48]. The electoral campaign in small size municipalities has become an arena for the expression of social divisions and conflicts between different groups of inhabitants, about local planning and public action issues [49]. On this basis, it is appropriate to assume that a mayor who seeks to be re-elected has to comply with the demand for landscape preservation from the majority. Depending on the municipality, this demand can come from either newcomers or long-standing residents and farmers.

\subsection{Landscape preservation: a provision of local public good}

As mentioned above, this study retains the median voter model as its benchmark for explaining the decisions reached by municipalities relating to environmental zoning as part of a river basin plan. The median-voter model is usually employed to explain spending and fiscal behaviour of local government based on the preferences of the voter with the median income [50] and [51, p.244]. Our theoretical development begins with the assumption that the local government behaves as if it maximised the utility of the voter with the median income, to define the level of local spending for the preservation of landscape amenities, and the optimal tax rate to finance it. The model is thus made up of two components: demand and supply.

For demand, each resident $i$ is supposed to derive utility from the consumption of private commodity goods $C_{i}$ and preservation of landscape amenities (scenic views, recreational opportunities) $A_{i}$, that add to the quality of life $Q_{i}, Q_{i}=Q_{i}\left(A_{i}\right)$ in the municipality of residence, according to individual $i$ preference for landscape amenities, $\alpha_{i}, 0 \prec \alpha_{i} \leq 1$. The utility function is thus expressed as follows: $U_{i}=U\left(C_{i} ; A\right)=C_{i}+\alpha_{i} Q_{i}\left(A_{i}\right)$. The resident would maximise this utility function with an individual consumption and demand for landscape amenities that are compatible with his/her budget constraints. This means that his/her income $Y_{i}$ has to cover both the consumption of private goods for which the price $\mathrm{p}$ is equal to unity (for convenience) and to the payment of the local tax as a proportion $(t)$ of his/her individual demand of landscape preservation: $Y_{i}=C_{i}+t^{*} A_{i}$. 
On the supply side, the budget constraints of a given municipality imply that the amount of local public spending for environmental protection depends on the financial contribution of all permanent resident population. Following [52], it means that in order to preserve landscape amenities, the municipality will spend for each resident an amount $\bar{A}$ which is an increasing function of the average value of individual incomes at municipality level $\bar{Y}=\frac{\sum_{N} Y_{i}}{N}$ (when the population size is $N)$, and the local tax rate $t: \bar{A}=\bar{Y}\left(t-t^{2} / 2\right)$ where $\mathrm{t} \in(0,1)$. Therefore, the optimal rate of taxation is defined at the level for which the supply side of landscape preservation matches average demand.

Evidently, from the elected officials' point of view, the local spending supply should correspond to the demand of the voter who earns the median income: $\bar{A}=A_{m}$. Thus, the entire maximisation problem of the municipal authority can be specified as follows:

$$
\left\{\begin{array}{l}
\text { Max } U_{m}=U\left(C_{m} ; A_{m}\right)=C_{m}+\alpha_{m} Q_{m}\left(A_{m}\right) \\
\text { with respect to }\left\{\begin{array}{l}
Y_{m}=C_{m}+t^{*} A_{m} \\
\bar{A}=\bar{Y}\left(t-t^{2} / 2\right) \\
\bar{A}=A_{m}
\end{array}\right.
\end{array}\right.
$$

where $m$ indicates the median voter. The indirect utility associated with equation (1) takes the following form: $V_{m}=(1-t) Y_{m}+\alpha_{m} Q_{m}\left(\bar{Y}\left(t-t^{2} / 2\right)\right)$. Usually, individual preference is supposed to be single-peaked, meaning that the utility function $V_{m}$ is continuous, strictly increasing and strictly quasi-concave with respect to $t$. The derivative of this indirect utility function with respect to the tax rate $t$ gives the optimal tax rate $t^{*}$ to be paid by all residents in a municipality. It corresponds to the level of tax the median voter is willing to pay for landscape preservation:

$$
t^{*}=t_{m}=1-\frac{Y_{m}}{\bar{Y}} * \frac{1}{\alpha_{m} *\left(\partial Q_{m} / \partial A_{m}\right)}
$$

When the marginal benefit of local spending on landscape amenity preservation in terms of quality of life is constant for all residents including the median voter : $\partial Q_{m} / \partial A_{m}=k$, the optimal tax rate function defined by equation (2) could be rewritten as follows: 
$t^{*}=t_{m}=1-R_{m} * \frac{1}{\alpha_{m} k}$ (with $R_{m}=\frac{Y_{m}}{\bar{Y}}$ the relative income of the median voter). This means that the optimal tax rate depends on the relative income $R_{m}$ of the median voter and his/her preference $\alpha_{m}$ for landscape amenities.

A value of $R_{m}$ lower than 1 signifies that the majority of the population receives belowaverage income. It indicates unequal distribution of income within each municipality. In this way, the optimal taxation rate for the preservation of landscape amenities is positively correlated to economic equity as measured at municipality level. However, the optimal taxation rate also depends on the value of the parameter $\alpha_{m}$. Thus, between two communities with identical income distribution, if the majority of the population is composed of newcomers and has a preference for natural areas (meaning that $\alpha_{m}$ is larger and tends to one) for the first, while the majority has a preference for the maintaining of agricultural landscape and the associated economic activity ( $\alpha_{m}$ tends to zero) for the second, the optimal taxation rate will be higher in the former municipality.

\subsection{Landscape preservation and environmental zoning}

At this stage, it is interesting to examine the relationships between the optimal taxation rate, median voter demand for landscape preservation, and local authority decisions on environmental zoning. First of all, the median voter may benefit from land-use restrictions, but an increase in the number of permanent residents can be desirable in maintaining landscape amenities and other local public goods. A higher local tax is likely to be called upon to fill the gap. The resulting variation in the optimal taxation rate then takes the following form if environmental zoning takes place:

$$
d t^{*}=d t_{m}=\partial t_{m} / \partial R_{m}=\frac{1}{\alpha_{m} k}\left[-1+\frac{R_{m}}{\alpha_{m}} * \frac{\partial \alpha_{m}}{\partial R_{m}}\right]
$$

Expression (3) will be positive: $\partial t_{m} / \partial R_{m} \geq 0$, if the relative income elasticity of preference for the landscape preservation $\frac{R_{m}}{\alpha_{m}}\left(\partial \alpha_{m} / \partial R_{m}\right)$ takes a positive value higher than 1. This assumption means that poorer median voters (whose income is below the average of their 
social group) care less about the preservation of the environment than their higher income counter-parts. The value of the willingness to pay for the preservation of the quality of the landscape is thus an increasing function of the relative income (of the median voter) [53] and [54]. In other words, richer (than the average) median voters might prefer additional environmental zoning and land-use restrictions to prevent the degradation of the natural landscape, and are thus willing to take on the additional tax burden for the associated increase in public expenditure. Consequently, increasing the local tax rate to finance the preservation of more natural landscapes would be easier to implement in egalitarian communities. The decision of local politicians to adopt additional environmental zoning would be an increasing function of the relative income level (of the median voter) in their municipality.

Furthermore, between two communities with identical relative income, if the majority of the population is composed of newcomers and has a preference for natural areas, then application of the river basin plan would not find too much local resistance. However, if the landscape preference of the majority is for the preservation of agricultural landscape, river basin plan impacts on the future patterns of the municipality landscape has to conform to this. Therefore, we can also assume that the vote of the elected official would be related to the increase of the proportion of newcomers at municipality level.

\section{An empirical application: the adoption of the SAGE for the Gironde estuary and its} associated areas

\subsection{The study case}

In France, the origins of the river basin approach to water resource management can be traced back to the late 60s. The country already had a mature system of river basin management before the implementation of the Water Framework Directive [55]. The shift to more integrated water resource management at river basin scale can thus rely on existing institutions. The French water governance management system is made up of six river basin districts, in which River Basin Commitees (RBC) are responsible for defining the water policy. Water Agencies (Agences de l'Eau) are responsible for funding. Each RBC establishes the management plan and objectives for their river basin through the SDAGE (Schéma Directeur d'Aménagement et de Gestion de l'Eau). The demarcation of the SDAGE within 
local water boards (the CLE, Cellule Locale de l'Eau) at sub-basin level allows municipalities and other local stakeholders to construct water management plans.

The CLE is entrusted with the preparation of the content of the local version of the SDAGE, the SAGE (Schéma d'Aménagement et de Gestion de l'Eau), which is the French version of "RBMP" as defined in the WFD. This plan is aimed at ensuring compatibility between multiple uses of water and land at sub-basin level and the planning goals of the SDAGE, thus preserving water resources and aquatic ecosystems. To this end, the 2006 French law on water resources and aquatic ecosystems allows the PAGD to establish "priority areas" for conservation and restoration of water resources and aquatic ecosystems.

However, the political legitimacy of the SAGE is predominantly based on the outcomes of consultation with stakeholders of the CLE. They are called upon to position themselves in relation to the map of the "priority areas" as defined by the SAGE. Although disconnected from the final vote, this consultation procedure within the CLE is particularly important, regarding the number of the seats allocated to local government representatives (municipalities) - who hold half of all seats, at the expense of state representatives and other stakeholders.

Our empirical application focused on the implementation of the SAGE for the Gironde estuary and associated areas for the period 2014-2019. The scheme covers an area of $3800 \mathrm{~km} 2$ and 185 municipalities, including those of the Bordeaux urban region. The empirical analysis uses the results of votes on the SAGE, organised in December 2012 after six years of debates and procedures. However, as the analytical framework developed by this study suited the political context of municipalities located in the rural-urban interface area, 34 municipalities have been removed from the empirical study. Moreover, in this version of the SAGE, because of their strong urban profile, these municipalities were excluded from consideration for hosting some floodplain sites.

The counting of votes shows that only $35.7 \%$ of the 151 rural and peripheral communities called upon to express their position responded to the consultation, the others having abstained. To establish a consensus, the SAGE consultation phase seeks a unanimous result from municipality votes. Therefore, these cases of non-participation should be interpreted here as being closer to a yes response. Approval of the SAGE is then coded 1 (117 responses) and rejection is coded 0 (34 responses).

"Insert a figure of the map here" 


\subsection{The decision equation}

The position of each municipality authority on the SAGE can be derived from a latent variable $W^{*}$ that reflects the political benefit a mayor can expect when agreeing to river basin planning in order to protect water resources. He/she will vote yes to the river basin landuse planning when $W^{*} \geq 0$, but will refuse it when $W^{*} \prec 0$. This latent variable would be a positive function of the relative income of the median voter $Y_{m} / \bar{Y}$. Median voters have to share the cost of the public spending for landscape preservation with the other residents. The farther they are from the richest social group, the more they have influence on the decision of the mayor to agree on additional environmental zoning. In other terms, greater equality of income distribution at municipality level may facilitate the adoption of the river basin plan.

Population growth $P$ is another testing variable. This variable is used as proxy of the demographic change experienced by municipalities, and enables us to grasp the impact of residential development on municipalities' decision about environmental zoning, with regard to the landscape preference of newcomers. Indeed, "natural amenity-driven migration" was the main cause of rural gain of population elsewhere [56] and [57]. The impact of the population growth variable is expected to be positive. Municipalities which have experienced higher population growth have to conform to the demand for natural landscape preservation expressed mainly by new residents. They can thus obtain more benefit from river basin landuse planning.

The model should also introduce the proportion of agricultural land $S_{a g r i}$ at the municipality level, to indicate on the importance of agricultural activities. The proportion of forestland $S_{\text {for }}$ and wetland $S_{\text {wet }}$ in the municipality area should also be introduced as control variables to identify localities where natural landscapes are already predominant. Some municipalities had already implemented measures contained in Natura 2000 and other national conservation programmes to protect ecosystems that are home to remarkable habitats and species. These particular municipalities may therefore have rejected the river basin plan simply because they saw it as a form of "overkill". To indicate the proportion of municipality areas already classified as protected sites, a variable Nature was introduced as control variable for existing environmental zoning.

Finally, the distance to the nearest urban centre $D$ is also introduced to indicate the potential for residential development within a municipality, and the need (or lack of need) for a growth containment policy. This variable is considered to have a negative relationship with 
the probability of accepting environmental zoning, since municipalities closer to the urban centre are supposed to be more cautious about the environmental costs of urban sprawl. Ultimately, an error term $\varepsilon$ is introduced.

The decision equation is thus specified as follows:

$$
\operatorname{Pr} o b\left\{Y e s=1 \Leftrightarrow W^{*} \geq 0, W^{*}=W\left(Y_{m} / \bar{Y}, P, S_{a g r i}, S_{\text {for }}, S_{\text {wet }}, \text { Nature }, D ; \varepsilon\right)\right\}
$$

\subsection{Data sources for explanatory variables}

Table 1 gives the statistical details for explanatory variables. The first explanatory variable for the econometric analysis corresponds to the relative income of the median voter as measured at the municipality level as the ratio of median to average income. The data for this explanatory variable was obtained from the French National Statistics Database for the last year available (2009). The mean value of this variable is 0.86 , and $41 \%$ of the municipalities in the sample have a relative income (for the median voter) higher than this value. The increase in population between the last two censuses (1999 and 2009) is used to capture the impact of demographic change on elected official's decisions (as driven by the residential development).

The variables for land-use as measured by the proportions of farmland, forestland and wetland areas at municipality level are provided by Corine Land Cover 2006. The mean value of the proportion of agricultural land in each municipality for the sample is approximately $67 \%$. For a large majority $(60 \%)$ of the municipalities concerned by this study, more than $67 \%$ of the landscape is occupied by farmland. About $44 \%$ of the municipalities have wetlands in their territory. Forestland also concerns around $43 \%$ of the sample. These three variables are coded 1 when the respective proportion of area in the municipality is equal to or higher than the mean value of the sample, 0 otherwise. In addition, we take into consideration the proportion of natural areas that are already part of European or national conservation programmes. These specific conservation programmes concern 19\% of the sample.

Finally, in order to test the influence of urban externalities on the rural municipalities' decisions, we introduce as a control variable the distance to the nearest urban centre. For each observation, this variable was based on the Euclidean distance to Royan in the north and to Bordeaux in the south. Obviously, these two urban centres do not have the same potential for the surroundings municipalities. The larger city of Bordeaux is more likely to remain the 
centre for jobs and economic activities. The maintaining of growth in this city may result in sprawl. In contrast, the development of Royan is following a very low process but adopts the usual pathways of urban growth of coastal regions.

\section{"Insert Table 1 here"}

\subsection{The estimation method}

Our empirical estimation of equation (4) excludes the presence of strategic interaction between municipalities in the formulation of their votes, and assumes that the land-use decision of the mayor is guided solely by the median voter preference. Indeed, the results of the empirical investigation of local spending in France did not detect any strategic interaction between municipalities that have agreed on the collective delivery of specific local public goods within an intermunicipal organisation [58]. However, spatial dependence may persist between neighbouring municipalities. The omission of this effect in the econometric analysis can lead to spatial autocorrelation of error terms, without adequate econometric procedure. A logit version of equation (4) can be estimated and corrected for the spatial dependence of standard errors through the method outlined by Conley [28]. This method was chosen for its simplicity and efficiency, even for small samples. The spatial covariance estimator in Conley [28] is an application of the generalised method of moments procedure to compute an autocorrelation-consistent covariance matrix [59] in logit models with spatial auto-correlated errors.

\section{Spatial logit estimation of municipalities' votes}

\subsection{Model specification}

A first estimation of the econometric model of municipality approval of the SAGE incorporated all the independent variables described in section 3.3. Each municipality was identified geographically by the coordinates (latitude and longitude) of its centroid. The Conley procedure suggests a spatial dependence within five decimal degrees. The results of the estimation of the spatial logit version of this first regression are reported in Table 2 columns 2 and 3 (the results of the simple logit are provided in appendix A). The results of the estimation of Table 2 show that two variables, namely the proportion of forestland and 
wetland areas in the municipality are individually non-significant based on z-tests and very high $\mathrm{p}$ values. The variable indicating the proportion of wetland in the municipality is nonsignificant because of its collinearity with the variable for protected areas (Nature). It is also the case for the proportion of forestland areas. The mapping of protected areas and sites could indeed include forestland as well as wetland. To some extent, the proportion of forestland areas would be lower in municipalities with extensive agricultural land use. Before dropping forestland and wetland from the decision equation, the Wald test is used to ascertain that these two variables are jointly non-significant. The Fisher statistic takes the value of 0.32 with a pvalue of 0.85 . The null hypothesis that these two variables do not constitute direct explanatory variables of mayors' decisions is therefore confirmed. Forestland and wetland are skipped to come to a new version of the vote model.

With regard to the two variables for residential development, namely population growth and the distance to the nearest urban centre, only population growth still has a positive and significant effect on voting, while the effect of the dummy variable for the distance to the centre is nil. It is important to note that these two variables are independent according to a simple multicollinearity testing (by the calculation of correlation coefficient between population growth and distance to the nearest urban centre measured in kilometres). The econometric results would therefore appear to indicate that residential development does influence municipal authorities' decisions about environmental zoning. However, their decision is much more motivated by the need to respond to newcomers and non-farmer residents' wishes (these populations being more present in fast growing municipalities) than by the containment of urban sprawl. We also exclude the variable "distance" from the vote model.

Ultimately, the main explanatory factors of municipalities' decisions on river basin plans are: relative income, population growth, a dummy variable indicating whether the municipality hosts a large proportion of agricultural land, and the proportion of municipality areas protected by European and national programmes. The application of the Conley' procedure for this second regression has improved the significance of the variable "population growth". The results of the corresponding spatial logit regression are shown in Table 2 columns 4 and 5 (the simple logit is reported in the appendix A). The results of this second regression form the basis of comments and analysis. 


\subsection{Results}

Firstly, the empirical results obtained in this study support the use of the median voter model and its application in understanding the policy process behind municipalities' cooperation with river basin land-use planning. The sign of the estimated coefficients clearly corresponds to the expectations suggested by the theory. The effect of relative income was indeed strongly positive and highly significant. Moreover, the municipality decision on river basin land-use planning follows the median voter preference for landscape preservation, regarding the positive sign and the significance of the variable population growth. In other words, municipalities that had experienced faster population growth between the two census periods (1999 and 2006) were more likely to welcome newcomers and non-farmer residents. It is considered that these populations support natural landscape preservation.

Secondly, the negative sign and the significance of the ratio of farmland clearly indicates a decreasing marginal utility of the political benefit from agricultural landscape protection, which should not come as a surprise, given the retreat of agricultural activities and the promise of residential development in the majority of the municipalities under consideration. As may be seen from the examination of the impact of the proportion of municipality area protected by conservation programmes, SAGE environmental zoning is rejected by municipalities that are already home to Natura 2000 or other national protected sites. With a z-test of 1.60, the variable "Nature" was statistically non-significant with the first regression (Table 2 column 2), due to multicollinearity with forestland and wetland area variables. When these two variables are dropped from the econometric equation, "Nature" becomes significant (with a p-value of 5\%). This last result indicates that although the median voter could guide municipalities' positions relating to the SAGE, at this time, from the municipality point of view, the magnitude of protected areas has already reached their maximum threshold. Thus, an additional environmental zoning would not be necessary.

Finally, since the vote model was estimated with a logit equation, it is natural to consider the impact of dummy coded independent variables, namely the relative income and agricultural land-use proportion, with the calculation of the odds ratio. Odds ratio is defined as the ratio of the predicted probability of approving to the predicted probability of rejecting 
the plan when a dummy coded variable takes the value of one and the other variables in the model held constant. The value of the odds ratio is greater than 3 for relative income. This clearly indicates that the probability of approval of the SAGE zoning project is more than triple (3.24 times to be exact) when the municipality has a relative income higher than 0.86 . This result strongly suggests that finding economic equity should be also a preoccupation in river basin planning. The odds ratio for the proportion of agricultural areas is about 0.21 , meaning that the probability of rejection of the SAGE is quadrupled when the proportion of agricultural land extends to $67 \%$ of the municipality area. Maintaining agricultural land-use appears to be the major preoccupation of municipalities, where dense farmland is already present. This means that protecting the production of cereal (and to some extent the renowned Bordeaux wines) was the main driver of their decision to reject the SAGE. We cannot therefore rule out the influence of farmers 'organisations during the consultation process for the municipal approval of the SAGE. This last result highlights that the refusal of the river basin plan has a very strong political component with regard to the defence of agricultural activities in rural municipalities where agriculture is predominant.

\section{Discussion and conclusion}

More recently, it has been recognised that the main pressures on Europe's waters are also associated with the impacts of land-use and location options for development. Agriculture development and urbanisation have altered European surface waters by straightening rivers for irrigation or to protect against flooding. These activities result in damage to the morphology and hydrology of the water bodies [1], that can impact aquatic ecological fauna and flora, and reduce the natural retention capacities of riparian zones and floodplain. Specific policy tools such as zoning delineation are recognised as relevant instruments to challenge the issues addressed by urbanization and agriculture. But they do not alleviate the consequences of the logical division of competencies and responsibilities between the fields of water management and land-use planning.

This study adopts a political economy perspective to address the institutional barriers to the implementation of RBMP at local level. Local government interests often set the boundaries within which water resources can be protected and river-basin planning goals may be achieved. In the domain of land-use planning, local government interests could be strongly related to the landscape preferences of the majority of their residents as predicted by the median voter theorem. Thus, our theoretical development and empirical application support 
the idea that rural municipality's support for integrated land planning and water resources management is conditional on newcomer and non-farmer resident landscape preferences. In other words, economic equity and rapid demographic growth increase the approval rate for additional environmental zoning, given the continued and rapid land development in municipalities close to urban centre. This is more specifically the case in the southwest France (which includes our case study). Thus, we find that higher relative income as measured by the ratio of median to average income at municipality level and population growth significantly influence the position of municipal government on zoning "priority areas" to protect water resources.

Rural municipalities with a high proportion of agricultural land are shown to be against the SAGE zoning project. Indeed, it is important to note that integrated water resource management is often aligned with nature development for rural areas. The outcome of landuse planning for urban flood protection and water resource management is therefore rarely consistent with that of planning applied to farmland protection. However, some rural communities (albeit a minority) still rely on agricultural activities. They are the main opponents to integrated land planning and water resource management, and block collective coordination. Indeed, because of the critical role agriculture plays in the local economy, these rural municipalities derive lower economic benefits (residential development) and higher losses (decline of agricultural activities) from additional environmental zoning for water resource management purposes.

The results of the microeconomic analysis of municipalities' positions on river basin land-use planning for water resource management are consistent with the findings of previous studies on the complexity of the institutional interplay for water governance. They suggest that reorganising land-use planning and water management at the watershed scale has become the key to resolving the spatial mismatch between environmental processes and management decisions, but that it could generate new problems. Integrating land use planning and water management indeed tends to define priorities that could challenge other local policy fields, such as the preservation of agricultural land, local nature conservation programmes, or local development.

While our findings are not new, they highlight underlying political constraints in the process by which locally elected officials decide whether or not to support centralised principles of river basin planning and their associated outcomes. Thus, the clearest lesson learned from both this study and similar approaches to water resource management is the need for any future theoretical and empirical development of political economy analysis to move 
beyond debate on institutional incompatibility, and focus on understanding the political constraints affecting more "integrated" water resource management at local level, and proposals for their solutions. The literature on environmental federalism has examined this issue. Recent studies advanced the notion of "ecological fiscal transfer" [60] and open this up for future research agenda. They described explicitly intergovernmental fiscal transfers as innovative instrument to compensate municipalities for certain ecological services, they provide beyond their jurisdictional boundaries. The prospects for transferring this instrument to address municipality cooperation and agreement for river-basin management planning will have to be explored in details. 


\section{Acknowledgements}

The authors would like to thank Patrick Point and Alban Thomas for their helpful comments and suggestions. This study received financial support from the French Ministry of Ecology as part of its "Waters and Territories" research programme. The usual disclaimer applies.

\section{References}

[1] EEA, European waters - Assessment of status and pressures, EEA report $n^{\circ} 8$ (2012), 100p.

[2] M. Newson, Land, Water and Development. Sustainable Management of River Basin Systems, 2nd ed., Routledge, London, New York, 1997.

[3] T. Moss, Regional governance and the EU Water Framework Directive. Institutional Fit, Interplay and Scale, in: W.M. Lafferty, M. Narodslawsky(Eds.), Regional Sustainable Development in Europe. The Challenge of Multi-level Cooperative Governancen ProSus, Oslo, 2003, pp. 201-223.

[4] T. Moss, J. Newig, Multilevel water governance and problems of scale: Setting the stage for a broader debate, Environ. Manage. 46 (2010) 1-6.

[5] T. Moss, Spatial fit, from panacea to practice: Implementing the EU WaterFramework Directive, Ecology and Society 17 (2012).

http://dx.doi.org/10.5751/ES-04821-170302

[6] E. Herrfahrdt-Pähle, Applying the concept of fit to water governance reforms in South Africa, Ecology and Society 19 (2014).

http://dx.doi.org/10.5751/ES-05964-190125

[7] I. Theesfel, C. Schleyer, Germany's light version of integrated water resources management, Environmental Policy and Governance 23 (2013) 130-144.

[8] E. Mostert, River basin management and planning, Paper presented at 4th National Congress on Water Resources - Portuguese Water Resources Association (1998), Lisbon, 27 March.

[9] W. Huppert, IWRM and water governance: Striving for "incentive compatibility" in the water sector, paper presented at LARS: Catchment and Lake Research (2007), Univ. Siegen, Siegen, Germany.

[10] W. E. Oates, A reconsideration of environmental federalism, In: J. A. List, Zeeuw, A.D. (Eds.), Recent advances in environmental economics, Elgar, Cheltenham, 2002. 
[11] O. Young, The Institutional Dimensions of Environmental Change: Fit, Interplay, and Scale, MIT Press, Cambridge, Massachusets, USA.

[12] T. Moss, The governance of land use in river basins: prospects for overcoming problems of institutional interplay with the EU Water Framework Directive, Land Use Policy 21 (2004) 85-94.

[13] L. Lebel, P. Garden, M. Imammura, The politics of scale, position and place in the management of water resources in the Mekong region, Ecology and Society 10 (2005).

http://www.ecologyandsociety.org/vol10/iss2/art18

[14] P. Huntjens, C. Pahl-Wostl, J. Grin, Climate change adaptation in European river basins, Reg. Environ. Change 10 (2010) 263-284.

[15] OECD, Water governance in OECD countries: A multi-level approach, OECD Studies on Water (2011), OECD Publishing.

[16] C. Ferreyra, R.C de Loë, R.D. Kreutwiser, Imagined communities, contested watersheds: Challenges to integrated water resources management in agricultural areas, J. Rural Stud. 24 (2008) 304-321.

[17] M. Gullstrand, M. Löwgren, R. Castensson, Water issues in comprehensive municipal planning: a review of the Motala River Basin, J. Environ. Manage. 69 (2003) 239-247.

[18] A. Bhat, W. Blomquist, Policy, politics, and water management in the Guadalquivir river basin, Spain, Water Resour. Res. 40 (2004). doi:10.1029/2003WR002726

[19] J. G. Carter, Spatial planning, water and the Water Framework Directive: insights from theory and practice. Geographic Journal 173 (2007) 330-342.

[20] M. Wolsink, River basin approach and integrated water management: governance pitfalls for the Dutch space-water-adjustement management principle, Geoforum 37 (2006), 473-487.

[21] R. Plummer, D. de Grosbois, R. de Loë, J. Velaniskis, Probing the integration of land use and watershed planning in a shifting governance regime, Wat. Resour. Res. 47 (2011). doi:10.1029/2010WR010213.

[22] W. Blomquist, E. Schlager, Political pitfalls of intergrated watershed management, Soc. Natur. Resour. 18 (2005), 101-117.

[23] R.M. Saleth, Introduction to special section on river basin management: Economics, management, and policy, Water Resour. Res. 40 (2004). doi:10.1029/2004WR003368

[24] J. Ananda, W. Proctor, Collaborative approaches to water management and planning: An institutional perspective, Ecol. Econ. 86 (2013) 97-106. 
[25] R. G. Holcombe, The median voter in public choice theory. Public Choice 61 (1989) $115-125$

[26] W. A. Fischel, Politics in a dynamic view of land-use regulations: of interest groups and homevoters. J. Real Estate Financ. 31 (2005) 397-403.

[27] J. McDonald, D. McMillen, Determinants of suburban development controls: a Fischel expedition, Urban Stud. 41 (2004) 341-362.

[28] T. G. Conley, GMM estimation with cross sectional dependence, J. Econometrics 92 (1999) 1-45.

[29] M. Antrop, Landscape change and the urbanization process in Europe, Landscape Urban Plan. 67 (2004) 9-26.

[30] J. G. Carter, Spatial planning, water and the Water Framework Directive: insights from theory and practice. Geographic Journal 173 (2007) 330-342.

[31] J. McDonald, D. McMillen, Determinants of suburban development controls: a Fischel expedition, Urban Stud. 41 (2004) 341-362.

[32] M. Howell-Moroney, What are the determinants of open-space ballot measures? An extension of the research. Soc. Sci. Quart. 85 (2004) 169-179.

[33] J. D. Kline, Public demand for preserving local open space. Societ. Nat. Res.K. 19 (2006) 645-659.

[34] M. J. Kotchen, S.M. Powers, Explaining the appearance and success of voter referenda for open-space conservation. J. Envrion. Econ. Manag. 52 (2006) 373-390.

[35] E. Nelson, M. Uwasu, S. Polasky, Voting on open space: What explains the appearance and support of municipal-level open space conservation referenda in the United States? Ecol. Econ. 65 (2007) 580-593.

[36] J. Cavailhès, P. Wavresky, urban influences on periurban farmland prices. Eur. Rev. Agric. Econ. 30 (2003) 333-357.

[37] G. Livanis, C.B Moss, V.E. Breneman, R.F Nehring, U., Urban sprawl and farmland prices, Am. J. Agr. Econ. 88 (2006) 915-929.

[38] L.M. Hunter, J.D. Boardman, J.M.S. Onge, The association between rural amenities, rural population growth, and long-term residents' economic well-being, Rural Sociol. 70 (2005) 452-469

[39] R.L. Ryan, Local perceptions and values for a midwestern river corridor, Landscape Urban Plan. 42 (1998) 225-237.

[40] M. Arriaza, J.F. Cañas-Ortega, J.A. Cañas-Madueño, P. Ruiz-Aviles, Assessing the visual quality of rural landscapes, Landscape Urban Plan. 69 (2004) 115-125. 
[41] A. E. Buijs, Public support for river restoration. A mixed-method study into local residents' support for and framing of river management and ecological restoration in the Dutch floodplains, J. Environ. Manage. 90 (2009) 2680-2689.

[42] A. Adelaja, P.D. Gottlieb, The political economy of downzoning. Agr. Resource Econ. Rev. 38 (2009) 1-10.

[43] W. A. Fischel, The homevoter hypothesis, Harvard University Press, Cambridge, 2001.

[44] F. Ortalo-Magné, A. Pratt, The political economy of housing supply: homeowners, workers and voters. LCE STICERD Research paper n TE514 (2007) 38p.

[45] A. Solé-Ollé, E. Viladecans-Marsal, Lobbying, political competition and local land supply: recent evidence from Spain, J. Public Econ. 96 (2012) 10-19.

[46] I. Zasada, Multifunctional peri-urban areas - a review of societal demands and agricultural provision of goods and services, Land Use Policy 28 (2011) 639-648.

[47] R. Matthews, P. Selman, Landscape as a focus for integrating human and environmental processes, J. Agr. Econ. 57 (2006) 199-212.

[48] J-Y. Nevers, La participation aux élections municipales dans les communes rurales, in: B. Hervieu(Ed.), les Agriculteurs aux Urnes, L'Harmattan, Paris, 2008, pp. 111-123.

[49] S. Vignon, Un scrutin de "proximité” toujours participationniste? Quelques éléments de compréhension de la démobilisation autour des élections municipales, Savoir/agir 25 (2013) $13-22$.

[50] T.C. Bergstrom, R.P. Goodman, Private demands for Public goods, Am. Econ. Rev. 63 (1973) 280-296

[51] D.C. Mueller, Public Choice III, Cambridge: Cambridge University Press, 2003.

[52] E. Magnani, The environmnental Kuznets curve, environmental protection policy and income distribution, Ecol. Econ. 32 (2001) 431-443.

[53] H. Welsch, Implications of happiness research for environmental economics. Ecol. Econ. 68 (2009) 2735-2742.

[54] A. Kopmann, K. Rehdanz, A human well-being approach for assessing the value of natural land areas, Ecol. Econ. 93 (2013) 20-33.

[55] D. Liefferink, M. Wiering, Y. Uitenboogaart, The EU Water Framework Directive: A multi-dimensional analysis of implementation and domestic impact, Land Use Policy 28 (2011) 712-722.

[56] R.S. Glorioso, L.A.G. Moss, Amenity migration to mountain regions: Current knowledge and a strategic construct for sustainable development, Social Change 37 (2007) $137-161$ 
[57] H. Gosnell, J. Abrams, Amenity migration: Diverse conceptualizations of drivers, socioeconomic dimensions, and emerging challenges, GeoJournal 76 (2011) 303-322.

[58] Q. Frère, M. Leprince, S. Paty, The impact of intermunicipal cooperation on local public spending, Urban Stud. 19 (2013). doi:10.1177/0042098013499080

[59] W. K. Newey, K.D. West, A simple, positive semi-definite, heteroskedasticity and autocorrelation consistent covariance matrix, Econometrica 55 (1987) 703-708.

[60] I. Ring, Integrating local ecological services into intergovernmental fiscal transfers: The case of the ecological ICMS in Brazil, Land Use Policy 25 (2008) 485-497. 
Author-produced version of the article published in Water Resources and Economics, 2015, 9, 45-59

The original publication is available at http://www.sciencedirect.com/science/article/pii/S221242841400070X doi:10.1016/j.wre.2014.11.005

Figure 1. Spatial distribution of municipalities decisions in December 2012.

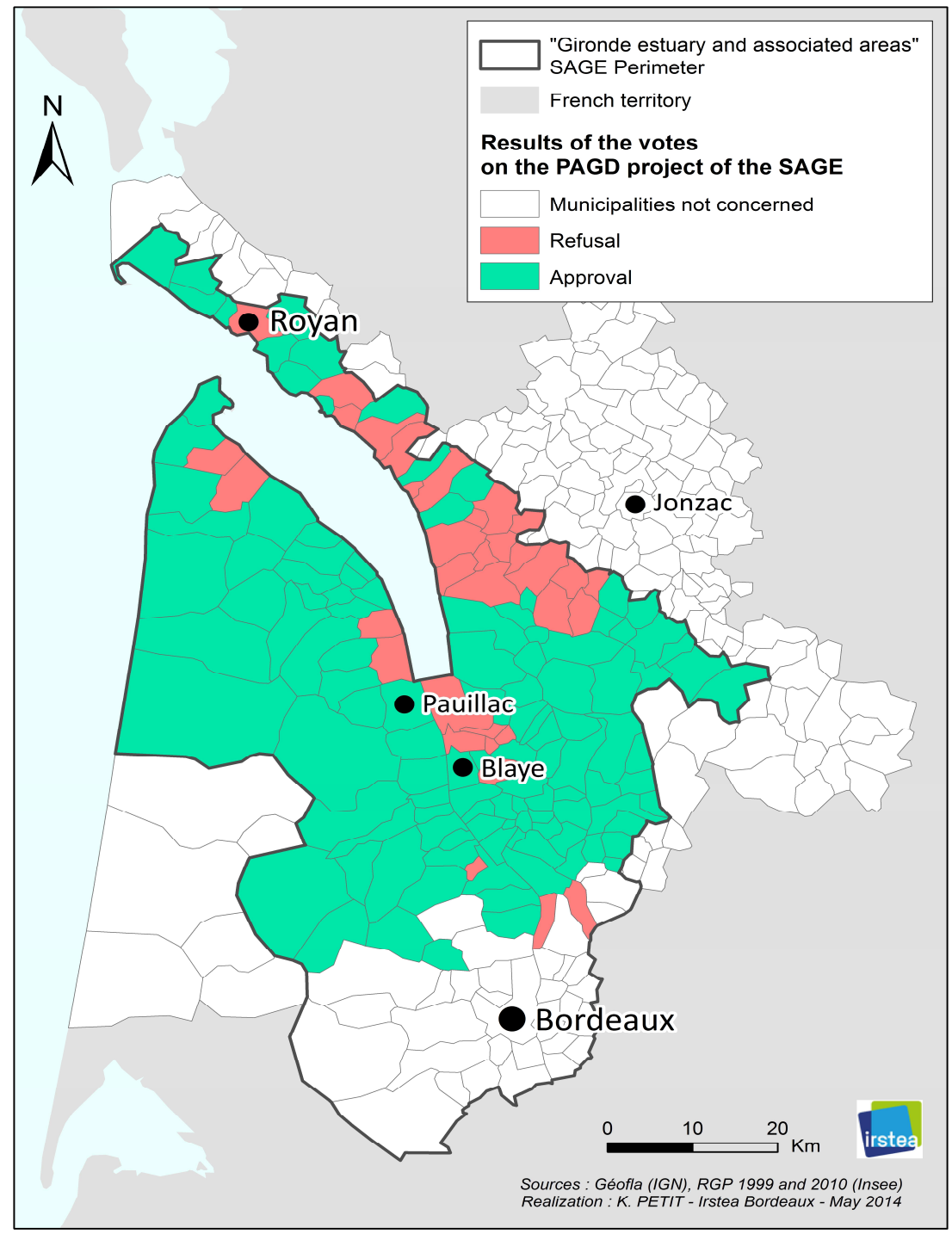


Table. 1 Summary statistics (Number of observations $=151$ )

\begin{tabular}{|c|c|c|c|c|}
\hline Variables & Mean value & $\begin{array}{l}\text { Standard } \\
\text { deviation }\end{array}$ & Minimum & Maximum \\
\hline Municipality approval of the SAGE & $77.48 \%$ & & 0 & 1 \\
\hline Median income & 26467.99 & 5104.39 & 17888 & 49835 \\
\hline Average income & 30740.1 & 3614.29 & 21633 & 47677.36 \\
\hline Relative income & 0.86 & 0.15 & 0.47 & 1.27 \\
\hline $\begin{array}{l}\text { Municipality with higher relative income } \\
\text { (value>= mean value of the sample) }\end{array}$ & $41.06 \%$ & 49.35 & 0.00 & 1.00 \\
\hline $\begin{array}{l}\text { Population growth: Evolution of the } \\
\text { population between } 1999 \text { and } 2009(\%)\end{array}$ & 12.82 & 12.93 & -14.80 & 61.26 \\
\hline $\begin{array}{l}\text { Proportion of agricultural land in the total } \\
\text { municipality area (\%) }\end{array}$ & 66.89 & 26.12 & 4.66 & 99.00 \\
\hline $\begin{array}{l}\text { Municipality with higher proportion of } \\
\text { agricultural area (value }>=\text { mean value of } \\
\text { the sample) }\end{array}$ & $58.94 \%$ & 49.35 & 0 & 1 \\
\hline $\begin{array}{l}\text { Proportion of forestland in the total } \\
\text { municipality area (\%) }\end{array}$ & 13.86 & 11.43 & 0.00 & 48.38 \\
\hline $\begin{array}{l}\text { Municipality with higher proportion of } \\
\text { forest area (value }>=\text { mean value of the } \\
\text { sample) }\end{array}$ & $43.04 \%$ & 49.67 & 0.00 & 1.00 \\
\hline $\begin{array}{l}\text { Proportion of wetland in the total } \\
\text { municipality area }(\%)\end{array}$ & 5.20 & 11.62 & 0.00 & 53.34 \\
\hline $\begin{array}{l}\text { Municipality with higher proportion of } \\
\text { wetland area (value >= mean value of the } \\
\text { sample) }\end{array}$ & $43.70 \%$ & 49.76 & 0.00 & 1.00 \\
\hline $\begin{array}{l}\text { Proportion of municipality area covered by } \\
\text { the European Natura } 2000 \text { network (\%) }\end{array}$ & 19.01 & 24.05 & 0.00 & 98.24 \\
\hline $\begin{array}{l}\text { Distance to the nearest } \\
\text { urban centre (in } \mathrm{km} \text { ) }\end{array}$ & 30.75 & 12.19 & 0.00025 & 53.99 \\
\hline $\begin{array}{l}\text { Distance to the nearest } \\
\text { urban centre }<=30 \mathrm{~km} \text { ) }\end{array}$ & $47.00 \%$ & 50.00 & 0.00 & 1.00 \\
\hline
\end{tabular}


Appendix A: Results of the simple logit model estimations

\begin{tabular}{|c|c|c|c|c|}
\hline \multirow{2}{*}{$\begin{array}{l}\text { Dependent variable : Municipality approval } \\
\text { of the SAGE } \\
\text { Independent variables }\end{array}$} & \multicolumn{2}{|c|}{ Model 1} & \multicolumn{2}{|c|}{ Model 2} \\
\hline & Coef. Est & Z-test & Coef. Est & Z-test \\
\hline Municipality with higher relative income & $\begin{array}{l}0.98 * \\
(0.59)\end{array}$ & 1.67 & $\begin{array}{l}1.18 * * \\
(0.55)\end{array}$ & $2.12 * *$ \\
\hline $\begin{array}{l}\text { Municipality with higher proportion of } \\
\text { agricultural areas }\end{array}$ & $\begin{array}{c}-1.59 * * * \\
(0.56)\end{array}$ & -2.82 & $\begin{array}{c}-1.57 * * * \\
(0.54)\end{array}$ & -2.90 \\
\hline $\begin{array}{l}\text { Municipality with higher proportion of } \\
\text { forest areas }\end{array}$ & $\begin{array}{l}-0.19 \\
(0.53)\end{array}$ & -0.37 & & \\
\hline $\begin{array}{l}\text { Municipality with higher proportion of } \\
\text { wetlands areas }\end{array}$ & $\begin{array}{c}0.28 \\
(0.66)\end{array}$ & 0.42 & & \\
\hline $\begin{array}{l}\text { Proportion of municipality area covered by } \\
\text { European and national conservation } \\
\text { programmes }(\%)\end{array}$ & $\begin{array}{l}-0.02 * \\
(0.01)\end{array}$ & -1.93 & $\begin{array}{l}-0.02 * \\
(0.01)\end{array}$ & -1.94 \\
\hline Population growth & $\begin{array}{l}0.05^{* *} \\
(0.02)\end{array}$ & 2.31 & $\begin{array}{l}0.05 * * \\
(0.02)\end{array}$ & 2.31 \\
\hline $\begin{array}{l}\text { Distance to the nearest } \\
\text { urban centre }<=30 \mathrm{~km}\end{array}$ & $\begin{array}{c}0.38 \\
(0.53)\end{array}$ & 0.73 & & \\
\hline Constant & $\begin{array}{c}1.83 * * * \\
(0.70)\end{array}$ & 2.59 & $\begin{array}{c}1.85 * * * \\
(0.60)\end{array}$ & 3.13 \\
\hline Pseudo-R ${ }^{2}$ & 0.22 & & 0.22 & \\
\hline Number of observations & 151 & & 151 & \\
\hline
\end{tabular}

Notes: ***: significant at 1\%; **: significant at 5\%; *: significant at 10\%; Standard errors in parentheses. 
Table 2: Results of the spatial logit model estimations

\begin{tabular}{|c|c|c|c|c|}
\hline \multirow{2}{*}{$\begin{array}{l}\text { Dependent variable : Municipality approval } \\
\text { of the SAGE } \\
\text { Independent variables }\end{array}$} & \multicolumn{2}{|c|}{ Model 1} & \multicolumn{2}{|c|}{ Model 2} \\
\hline & Coef. Est & Z-test & Coef. Est & $\overline{\text { z-test }}$ \\
\hline Municipality with higher relative income & $\begin{array}{l}0.98 * * \\
(0.45)\end{array}$ & 2.19 & $\begin{array}{l}1.18 * * \\
(0.54)\end{array}$ & 2.17 \\
\hline $\begin{array}{l}\text { Municipality with higher proportion of } \\
\text { agricultural areas }\end{array}$ & $\begin{array}{c}-1.59 * * * \\
(0.52)\end{array}$ & -3.06 & $\begin{array}{c}-1.57 * * * \\
(0.46)\end{array}$ & -3.40 \\
\hline $\begin{array}{l}\text { Municipality with higher proportion of } \\
\text { forest areas }\end{array}$ & $\begin{array}{l}-0.20 \\
(0.34)\end{array}$ & -0.57 & & \\
\hline $\begin{array}{l}\text { Municipality with higher proportion of } \\
\text { wetlands areas }\end{array}$ & $\begin{array}{c}0.28 \\
(0.75)\end{array}$ & 0.37 & & \\
\hline $\begin{array}{l}\text { Proportion of municipality area covered by } \\
\text { European and national conservation } \\
\text { programmes }(\%)\end{array}$ & $\begin{array}{l}-0.02 \\
(0.02)\end{array}$ & -1.60 & $\begin{array}{l}-0.02 * * \\
(-0.01)\end{array}$ & -2.04 \\
\hline Population growth & $\begin{array}{c}0.05^{* * *} \\
(0.01)\end{array}$ & 3.64 & $\begin{array}{c}0.05^{* * *} \\
(0.01)\end{array}$ & 4.63 \\
\hline $\begin{array}{l}\text { Distance to the nearest } \\
\text { urban centre }<=30 \mathrm{~km}\end{array}$ & $\begin{array}{c}0.39 \\
(0.41)\end{array}$ & 0.93 & & \\
\hline Constant & $\begin{array}{c}1.83 * * * \\
(0.60)\end{array}$ & 2.71 & $\begin{array}{c}1.85 * * * \\
(0.50)\end{array}$ & 3.71 \\
\hline Pseudo-R $\mathrm{R}^{2}$ & 0.22 & & 0.22 & \\
\hline Number of observations & 151 & & 151 & \\
\hline
\end{tabular}

Notes: ***: significant at 1\%; **: significant at 5\%; *: significant at 10\%. Standard errors in parentheses. 